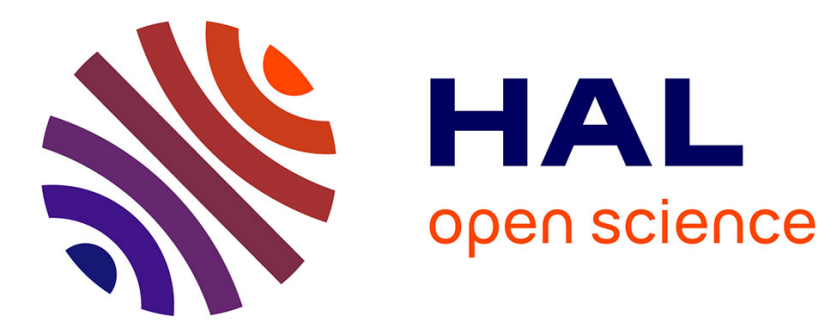

\title{
A calibrated radiocarbon database of late Quaternary volcanic eruptions
}

\author{
R. U. Bryson, R. A. Bryson, A. Ruter
}

\section{To cite this version:}

R. U. Bryson, R. A. Bryson, A. Ruter. A calibrated radiocarbon database of late Quaternary volcanic eruptions. eEarth Discussions, 2006, 1 (2), pp.123-134. hal-00298245

\section{HAL Id: hal-00298245 \\ https://hal.science/hal-00298245}

Submitted on 25 Jul 2006

HAL is a multi-disciplinary open access archive for the deposit and dissemination of scientific research documents, whether they are published or not. The documents may come from teaching and research institutions in France or abroad, or from public or private research centers.
L'archive ouverte pluridisciplinaire HAL, est destinée au dépôt et à la diffusion de documents scientifiques de niveau recherche, publiés ou non, émanant des établissements d'enseignement et de recherche français ou étrangers, des laboratoires publics ou privés. 


\section{A calibrated radiocarbon database of late Quaternary volcanic eruptions}

R. U. Bryson ${ }^{1}$, R. A. Bryson ${ }^{2}$, and A. Ruter ${ }^{2}$

${ }^{1}$ National Park Service, Mojave National Preserve, 2701 Barstow Road, Barstow, CA 92311, USA

${ }^{2}$ Center for Climatic Research, University of Wisconsin-Madison, 1225 W. Dayton St., Madison, WI 53706, USA

Received: 24 May 2006 - Accepted: 17 July 2006 - Published: 25 July 2006

Correspondence to: A. Ruter (ahruter@wisc.edu)
$1,123-134,2006$

A cal 14-C late quaternary eruption database

R. U. Bryson et al.

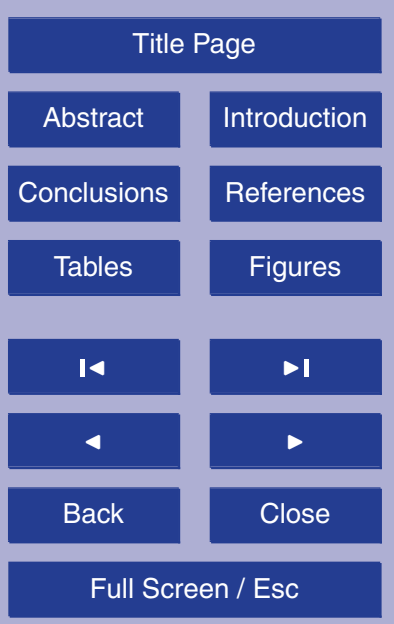

Printer-friendly Version

Interactive Discussion 


\section{Abstract}

Researchers at the Center for Climatic Research (CCR) at the University of WisconsinMadison have revised and calibrated a global volcanic database compiled from more than 2000 radiocarbon-dated eruptions from the late Pleistocene and Holocene. 5 The updated database is available online as an appendix to this correspondence (http://www.electronic-earth-discuss.net/1/123/2006/eed-1-123-2006-supplement.zip). We briefly describe the database, suggest some potential applications, and invite other researchers in the geologic and atmospheric sciences to both use and help refine the archive by incorporating additional data as it becomes available.

\section{Introduction}

Volcanic eruptions inject $\mathrm{SO}_{2}$ into the atmosphere where it oxidizes to $\mathrm{H}_{2} \mathrm{SO}_{4}$. These aerosolized droplets of sulfuric acid scatter incoming solar radiation. Although complex, the net effect of these aerosols is increased albedo, which cools the planet (Robock, 2000). The cooling produced by individual eruptions may last only a few years, but cumulative effect of multiple eruptions may significantly modulate the more gradual climatic oscillations driven by orbital forcing (Bryson, 1988; Bryson and Goodman, 1980; Hammer et al., 1980; Robock, 2000; Zielinski, 2000). Conversely, these low frequency oscillations in the planet's orbital geometry force the accumulation of continental glaciers. Several recent studies on the Pacific coast of North America and the North Atlantic (Jellinek et al., 2004; Maclennan et al., 2002; Mortensen et al., 2005; Sigvaldason et al., 1992; Slater et al., 1998) have linked significant increases in volcanism to the isostatic rebound resulting from the ablation of these ice masses. Additionally, several general circulation model (GCM) experiments also suggest that hemispheric cooling of significant amplitude and duration can be expected from the combined effects of multiple eruptions (Kirchner and Graf, 1995; Pollack et al., 1993). Other factors, including secular variation in solar output (Bond et al., 2001), may have
$1,123-134,2006$

\section{A cal 14-C late quaternary eruption database}

R. U. Bryson et al.

\section{Title Page}

Abstract

Introduction

Conclusions

Tables

References

Figures

I

14

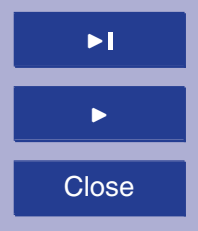

Back

Close 
contributed to high frequency temperature oscillations during the Holocene as well.

Nearly thirty years ago researchers at the Center for Climatic Research compiled an archive of radiocarbon-dated volcanic eruptions to track variation in global volcanism during the Holocene and late Pleistocene (Bryson and Goodman, 1980; Bryson and 5 Bryson, 1998). The goal was to estimate changes in the rate of global eruptions and to begin to evaluate the role of volcanism in Holocene climate change. An early iteration of the database was made available through the NOAA Paleoclimate archive in the 1990s: ftp://ftp.ncdc.noaa.gov/pub/data/paleo/climate_forcing/bryson1988/. This uncalibrated database comprised about 1000 eruptions. The current record has 10 been enlarged and revised and now contains 2021 entries. The following briefly describes the database, the calibration method used, and presents two indices calculated from the data. The new database is available as an online appendix (http://www.electronic-earth-discuss.net/1/123/2006/eed-1-123-2006-supplement.zip) to this correspondence in Excel format. It provides the coordinates, countries, probable 15 source eruption, radiocarbon age and standard deviation, and calibrated ranges at 68 and 95 percent probabilities, as well as notes and references.

The product should be of interest to researchers examining possible periodicities in the rates of regional or global volcanism (Jupp et al., 2004), those interested in the dynamics of glacial loading and volcanism, and climate scientists interested in high frequency variations driven by volcanic aerosols. We have worked to keep the database current, incorporating new dates as they became available, but new research (especially marine coring projects) has the potential to significantly increase the number of eruptions dated to the late Quaternary.

\section{The database}

25 Some researchers have argued that a representative record of global volcanism cannot be derived from terrestrial sediments because of the irregular preservation and recovery of ejecta (Zielinski et al., 1996). We acknowledge these reservations but argue
$1,123-134,2006$

\section{A cal 14-C late quaternary eruption database}

R. U. Bryson et al.

\section{Title Page}

Abstract Introduction

Conclusions References

Tables Figures
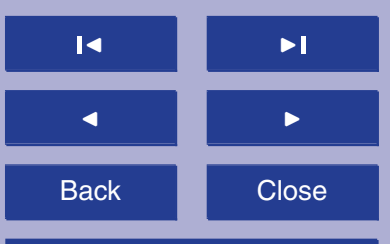

Back

Close

Full Screen / Esc

Printer-friendly Version

Interactive Discussion 
that the geological record is important, because it may preserve a component of the global volcanic signal that is less evident in ice cores due to the irregular advection of volcanic aerosols. Greenland's volcanic record, for example, is known to be strongly influenced by Icelandic volcanoes (Hammer et al., 1980). Although significant inter-pole 5 correspondence has been demonstrated (Bay et al., 2006), high latitude records have a general bias toward their respective hemispheres (Robock, 2000). The geological index presented here is relatively unbiased; eruptions in the geological database range from $54^{\circ} \mathrm{S}$ to $79^{\circ} \mathrm{N}$ latitudes. Volcanoes located north of $45^{\circ} \mathrm{N}$ comprise only $24 \%$ of the record, while fully $39 \%$ are from the tropics. Bay et al. (2004) found significant 10 correspondence between a volcanic index calculated from our geological database (described below) and the rates of volcanic dust accretion in ice cores from both poles, suggesting that the index may track the global signal in both records.

Simkin and Siebert have compiled an extensive general volcanic database (1994), but it is primarily historic. Out of the total 9112 eruptions reported, 3599 erupted after 151900 (39\%), and only $27 \%$ erupted before AD 1500 . The most recent version (online at http://www.volcano.si.edu/world/) includes 1297 radiocarbon-dated eruptions of which 338 are calibrated. We have compared our database with the Smithsonian archive for correspondence and redundancy but have not incorporated any prehistoric dates from methods other than radiocarbon. We have culled all duplicate dates so that single eruptions are not recorded more than once.

According to Simkin and Siebert, eruptions in remote regions were not consistently reported prior to about 1950. Thus a historical survey of global eruptions reliable enough to calculate a rate spans only the last 50 years (Simkin and Siebert, 1994). Their database lists nearly 2000 eruptions between 1950 and 1994 (Siebert 25 and Simkin, 2002). However, according to the volcanic explosivity index (VEI) that they provide, most of these were minor eruptions producing only small quantities of ejecta and aerosols. Ancient eruptions of this magnitude probably left little trace in the geological or cryological records. Comparison with the Smithsonian historical archive suggests that our geological database is apt to be a very small sample of the total

$1,123-134,2006$

\section{A cal 14-C late quaternary eruption database \\ R. U. Bryson et al.}

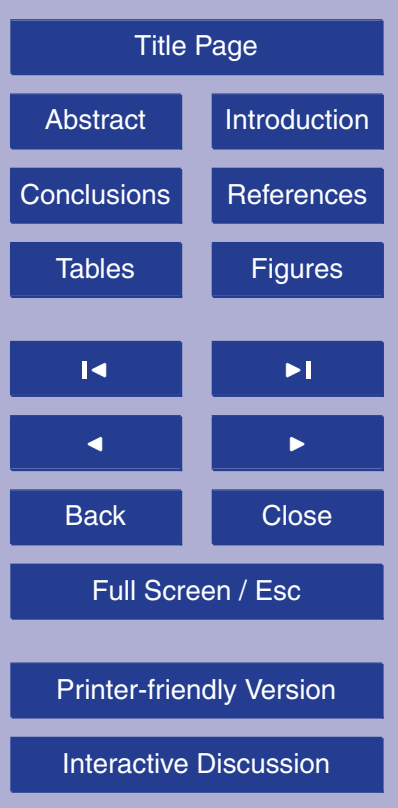


number of eruptions during the last 40000 years, as Zielinski et al. (1996) suggest. Yet it may be more representative of the most explosive eruptions, which produced a large volume of well-dispersed ejecta and inject $\mathrm{SO}_{2}$ into the stratosphere where it can be broadly circulated.

5 Temporal resolution in a radiocarbon database is likewise limited by the errors associated with the age estimation and calibration. We used the batch calibration function in the Cologne Radiocarbon Calibration \& Paleoclimate Research Package, or CalPal. We chose this program because it calculates a summed probability distribution of the calibrated ${ }^{14} \mathrm{C}$-ages, along with a single weighted intercept. This produces a 10 highly robust calibrated value for each conventional date, with associated one and twosigma distributions instead of multiple intercepts. Details of this method are given by Weninger (1986). Further information and a comparison with other calibration techniques are provided in the literature library on the CalPal site (http://www.calpal.de/). We have included the radiocarbon ages and standard deviations as columns in the database if more conventional calibration methods are preferred.

The database has been incorporated into the CalPal program as part of its paleoclimate archive. CalPal allows interactive plotting of the data against a range of other paleoclimate proxies including $\mathrm{SO}_{2}$ records from the GRIP, NGRIP, and Vostok cores.

Our version of the database is an Excel workbook with three worksheets. The first 20 consists of columns with the name of the source followed by its geographic region, latitude, longitude, and elevation when available. We have assigned a number to each entry to aid sorting. The radiocarbon age and standard deviation is followed by a calibrated single weighted intercept and its one sigma range. A two sigma calibrated age range is provided in a separate column followed by the date's laboratory sample number, abbreviated references, and comments. The second sheet has the same format but consists of those dates that could not be calibrated because no standard deviations were reported. The third worksheet lists the complete references alphabetically.
$1,123-134,2006$

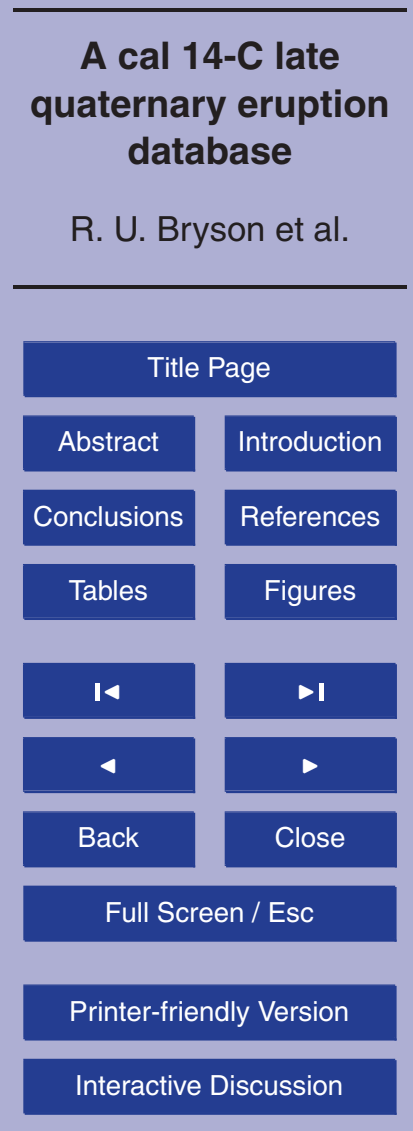




\section{Index of the volcanic rate}

We have calculated two indices after detrending to control for the effects of erosion and recovery of the older material. The earliest version of the index fitted a power law curve to the data to remove the trend due to preservation bias; the new index fits a 5 serpentine curve (given by the Cartesian equation $y=a b x / x^{2}+a^{2}$; Beyer, 1987:225), because it matches both the decay due to erosion and the fall off in radiocarbon dates on recent and historic eruptions (Fig. 1).

The departure from the curve (i.e. variance in the residuals) is expressed as a general index of the rate of volcanism over the past 14000 years in Fig. 2. Here we graph 10 both the summed probability under the curve and a frequency distribution using century bins.

A period of apparent increased volcanism associated with Northern Hemisphere deglaciation is evident in the index as well as in the $\mathrm{SO}_{2}$ record in the GRIP core (Zielinski et al., 1996; Zielinski and Mershon, 1997). Variation in the indices appears 15 to correspond with some well described climatic fluctuations in the Holocene, including the $4.1 \mathrm{~K}$ event, the Medieval Warm Period, and the Little Ice Age, suggesting that variation in global volcanism may have contributed to these events, consistent with other research (Hammer et al., 1980; Lamb, 1970; Robock, 2000; Robock and Free, 1996; Zielinski, 2000).

20 The index has been systematically incorporated into macrophysical climate models (Bryson and Bryson, 2000) to simulate late Quaternary variation due to volcanism. In the macrophysical models the variation in atmospheric albedo due to volcanism is estimated by correlating a record of measured optical depth with the record of historic eruptions for the same period of the 19th and 20th centuries (Goodman, 1978, 1984).

25 A recent study (Ruter et al., 2004) compared a set of compiled paleoclimate studies from the American tropics with simulations from four separate GCMs and the macrophysical model. The macrophysical retrodictions compared favorably with the compiled proxies and showed greater accuracy than most GCMs (all of which lacked a volcanic
$1,123-134,2006$

\section{A cal 14-C late quaternary eruption database \\ R. U. Bryson et al.}

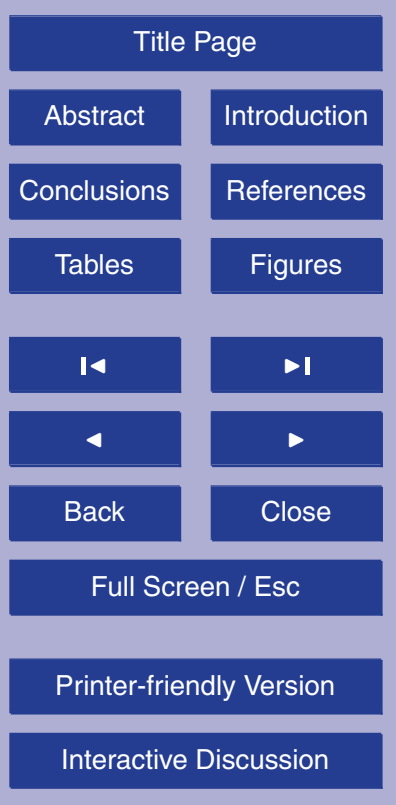


component). The effects of single and multiple eruptions at various spatial and regional scales have been the focus of several GCM experiments. However, with few recent exceptions (e.g. Mann et al., 2005), simulations of longer Holocene climate sequences typically omit volcanism. We note that just as some GCMs have been improved by the 5 incorporation of coupled ocean and vegetation feedbacks, the addition of volcanic modulation could further refine those GCMs attempting to simulate high-frequency climatic variation during the late Quaternary.

Despite the development of various volcanic indices (Goodman, 1984; Lamb, 1977, 1983; Mitchell, 1970; Robock and Free, 1995, 1996; Sato et al., 1993), significant 10 discrepancies remain between the various methods used to estimate both atmospheric optical depth and the proportion of its variation that can be explained by fluctuation in historic volcanism (Robock, 2000). This problem will not be easily resolved.

In conclusion, we know that this geologic archive is quite small given the general level of volcanism. We have reservations as to the representativeness of the record 15 in its current form and realize that polar ice holds the best archive of paleovolcanism. However current research involving the recovery and dating of volcanic ejecta from terrestrial contexts and marine cores (particularly those from the tropical Pacific) offer valuable new sources of additional data that should be incorporated. We hope that with further dissemination and augmentation this archive may develop into a useful complementary proxy for late Quaternary fluctuations in global volcanism.

\section{References}

Bay, R. C., Bramall, N., and Price, P. B.: Bipolar correlation of volcanism with millennial climate change, Proc. Natl. Acad. Sci., 101(17), 6341-6345, 2004.

Bay, R. C., Bramall, N., Price, P. B., Clow, G. D., Hawley, R., Udisti, R., and Castellano, E.: 25 period, J. Geophys. Res., 111, D11108, doi:1029/2005JD006306, 2006.

Beyer, W. H.: CRC Standard Mathematical Tables, 28th ed, CRC Press, 1987.

1, 123-134, 2006

\section{A cal 14-C late quaternary eruption database}

R. U. Bryson et al.

\section{Title Page}

Abstract Introduction

Conclusions References

Tables Figures

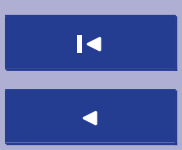
$>$ I

Full Screen / Esc

Printer-friendly Version

Interactive Discussion 
Bond, G., Kromer, B., Beer, J., Muscheler, R., Evans, M. N., Showers, W., Hoffmann, S., LottiBond, R., Hajdas, I., and Bonani, G.: Persistent Solar Influence on North Atlantic Climate during the Holocene, Science, 294, 2130-2136, 2001.

Bryson, R. A.: Late Quaternary Volcanic Modulation of Milankovitch Climate Forcing, Theor. Appl. Climat., 39, 115-125, 1988.

Bryson, R. A. and Bryson, R. U.: Site-Specific High-Resolution Models of the Monsoon for Africa and Asia, Global Planet. Change, 26, 77-84, 2000.

Bryson, R. A. and Goodman, B. M.: Volcanic Activity and Climatic Changes, Science, 207(7), 1041-1044, 1980.

10 Bryson, R. U. and Bryson, R. A.: Application of a Global Volcanicity Time-Series on HighResolution Paleoclimatic Modeling of the Eastern Mediterranean, in: Water, Environment and Society in Times of Climatic Change, edited by: Issar, A. S. and Brown, N., Kluwer Academic Publishers, Netherlands, 1-19, 1998.

Goodman, B. M.: Secular Variations of the Mean Annual Atmospheric Transparency in the Northern Hemisphere, MS thesis, University of Wisconsin-Madison, 1978.

Goodman, B. M.: The Climatic Impact of Volcanic Activity, PhD thesis, University of WisconsinMadison, 1984.

Hammer, C. U., Clausen, H. B., and Dansgaard, W.: Greenland ice sheet evidence of postglacial volcanism and its climatic impact, Nature, 288, 230-235, 1980.

20 Jellinek, A. M., Manga, M., and Saar, M. O.: Did melting glaciers cause volcanic eruptions in eastern California? Probing the mechanics of dike formation, J. Geophys. Res., 109(B9), B09206, doi:10.1029/2004JB002978, 2004.

Jupp, T., Pyle, D., Mason, B., and Dade, B.: A statistical model for the timing of earthquakes and volcanic eruptions influenced by periodic processes, J. Geophys. Res., 109, B02206, doi:10.1029/2003JB002584, 2004.

Kirchner, I. and Graf, H.-F.: Volcanos and El Niño: signal separation in Northern Hemisphere winter, Climate Dyn., 11(6), 341-358, 1995.

Lamb, H. H.: Volcanic Dust in the Atmosphere; with a Chronology and Assessment of Its Meteorological Significance, Philos. Trans. R. Soc. London. Ser. A, 266(1178), 425-533, 1970.

Lamb, H. H.: Supplementary volcanic dust veil index assessments, Clim. Monit., 6, 57-67, 1977.

Lamb, H. H.: Update of the chronology of assessments of the volcanic dust veil index, Clim.

\section{A cal 14-C late quaternary eruption database}

R. U. Bryson et al.

\section{Title Page}

Abstract

Introduction

Conclusions

References

Tables

Figures

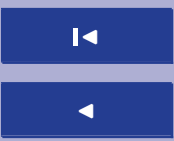

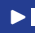

Back

$\triangleright$

Close

Full Screen / Esc

Printer-friendly Version

Interactive Discussion 
Monit., 12, 79-90, 1983.

Maclennan, J., Jull, M., McKenzie, D., Slater, L., and Grönvold, K.: The link between volcanism and deglaciation in Iceland, Geochem. Geophys. Geosyst., 3(11), 1062, doi:10.1029/2001GC000282, 2002.

5 Mann, M., Cane, M. A., Zebiak, S. E., and Clement, A.: Volcanic and Solar Forcing of the Tropical Pacific over the Past 1000 Years, J. Clim., 18, 447-456, 2005.

Mitchell, J. M.: A preliminary evaluation of atmospheric pollution as a cause of the global temperature fluctuation of the past century, in: Global Effects of Environmental Pollution, edited by: Singer, S. F., D. Reidel, Norwell, MA, 139-155, 1970.

10 Mortensen, A. K., Bigler, M., Grönvold, K., Steffensen, J. P., and Johnsen, S. J.: Volcanic ash layers from the Last Glacial Termination in the NGRIP ice core, J. Quat. Sci., 20(3), 209-219, 2005.

Pollack, J. B., Rind, D., Lacis, A., Hansen, J. E., Sato, M., and Ruedy, R.: GCM Simulations of Volcanic Aerosol Forcing. Part I: Climate Changes Induced by Steady-State Perturbations,

15 J. Clim., 6(9), 1719-1742, 1993.

Robock, A.: Volcanic Eruptions and Climate, Rev. Geophys., 38(2), 191-219, 2000.

Robock, A. and Free, M. P.: Ice cores as an index of global volcanism from 1850 to the present, J. Geophys. Res., 100(D6), 11549-11567, 1995.

Robock, A. and Free, M. P.: The volcanic record in ice cores for the past 2000 years, in: Climatic Variations and Forcing Mechanisms of the Last 2000 Years, edited by: Jones, P. D., Bradley, R. S., and Jouzel, J., Springer-Verlag, New York, 533-546, 1996.

Ruter, A., Arzt, J., Vavrus, S., Bryson, R. A., and Kutzbach, J. E.: Climate and environment of the subtropical and tropical Americas $(\mathrm{NH})$ in the mid-Holocene: comparison of observations with climate model simulations, Quat. Sci. Rev., 23, 663-679, 2004.

Sato, M., Hansen, J. E., McCormick, M. P., and Pollack, J. B.: Stratospheric Aerosol Optical Depths, 1850-1990, J. Geophys. Res., 98(D12), 22 987-22 994, 1993.

Siebert, L. and Simkin, T.: Volcanoes of the World: an Illustrated Catalog of Holocene Volcanoes and their Eruptions, Smithsonian Institution, Global Volcanism Program Digital Information Series, GVP-3, (http://www.volcano.si.edu/world/), 2002.

30 Sigvaldason, G. E., Annertz, K., and Nilsson, M.: Effect of glacier loading/deloading on volcanism: postglacial volcanic production rate of the Dyngjufjöll area, central Iceland, Bull. Volcanol., 54(5), 385-392, 1992.

Simkin, T.: Terrestrial volcanism in space and time, Annu. Rev. Earth Planet. Sci., 21, (A94-

\section{A cal 14-C late quaternary eruption database}

R. U. Bryson et al.

\section{Title Page}

Abstract

Introduction

Conclusions

References

Tables

Figures

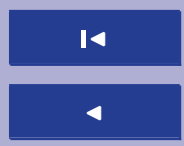

$\Delta$

Back

Close

Full Screen / Esc

Printer-friendly Version

Interactive Discussion 
10876 01-91), 427-452, 1993.

Simkin, T. and Siebert, L.: Volcanoes of the World: A Regional Directory, Gazetteer, and Chronology of Volcanism During the Last 10,000 Years, Geoscience Press, Inc., 1994.

Slater, L., Jull, M., McKenzie, D., and Grönvold, K.: Deglaciation effects on mantle melting under Iceland: results from the northern volcanic zone, Earth Planet. Sci. Lett., 164(1), 151164, 1998.

Weninger, B.: High-precision calibration of archaeological radiocarbon dates, Acta Interdisciplin. Archaeol., 4, Nitra, 11-53, 1986.

Zielinski, G. A.: Use of paleo-records in determining variability within the volcanism-climate system, Quat. Sci. Rev., 19, 417-438, 2000.

Zielinski, G. A., Mayewski, P. A., Meeker, L. D., Whitlow, S., and Twickler, M. S.: A 110,000-Yr Record of Explosive Volcanism from the GISP2 (Greenland) Ice Core, Quat. Res., 45(2), 109-118, 1996.

Zielinski, G. A. and Mershon, G. R.: Paleoenvironmental implications of the insoluble microparticle record in the GISP2 (Greenland) ice core during the rapidly changing climate of the Pleistocene-Holocene transition, Geol. Soc. Am. Bull., 109(5), 547-559, 1997.
$1,123-134,2006$

\section{A cal 14-C late quaternary eruption database \\ R. U. Bryson et al.}

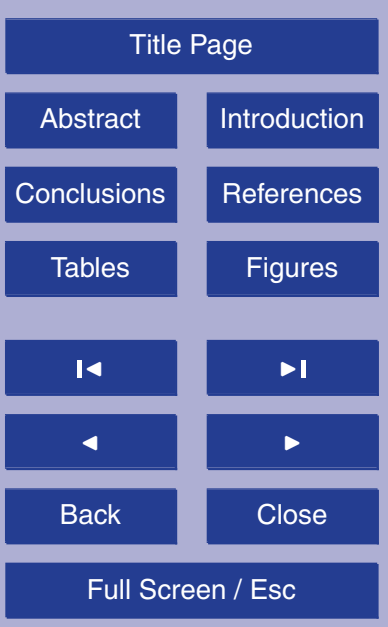

Printer-friendly Version

Interactive Discussion 
VOLCANIC COUNT DATA

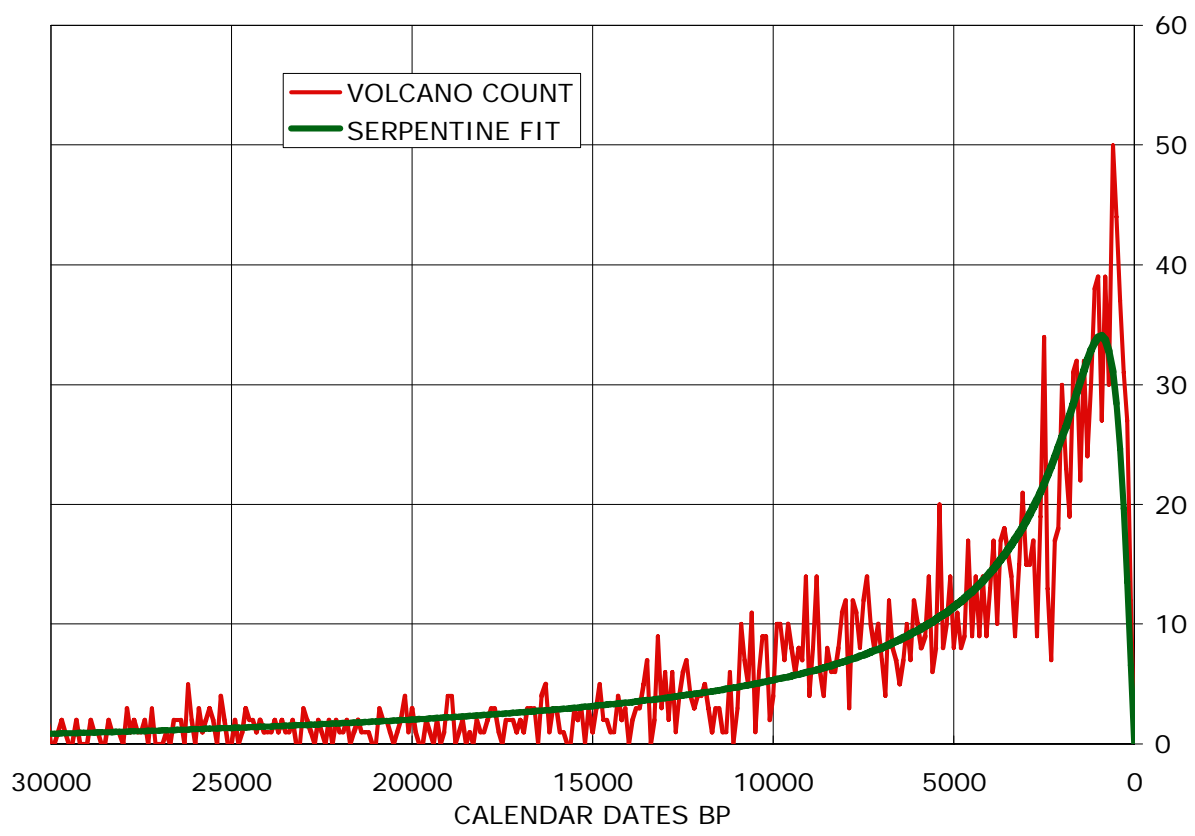

Fig. 1. A frequency distribution of the calibrated ages with the fitted serpentine curve used to detrend the data. The residual variance (Fig. 2) is the volcanicity index.

\section{A cal 14-C late quaternary eruption database}

R. U. Bryson et al.

\section{Title Page}

Abstract

Introduction

Conclusions

References

Tables

Figures

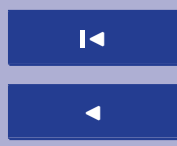

Back

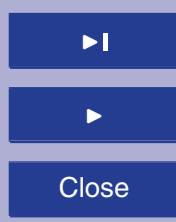

Full Screen / Esc

Printer-friendly Version

Interactive Discussion 
ESTIMATED VOLCANIC INDEX SERPENTINE NORMALIZATION

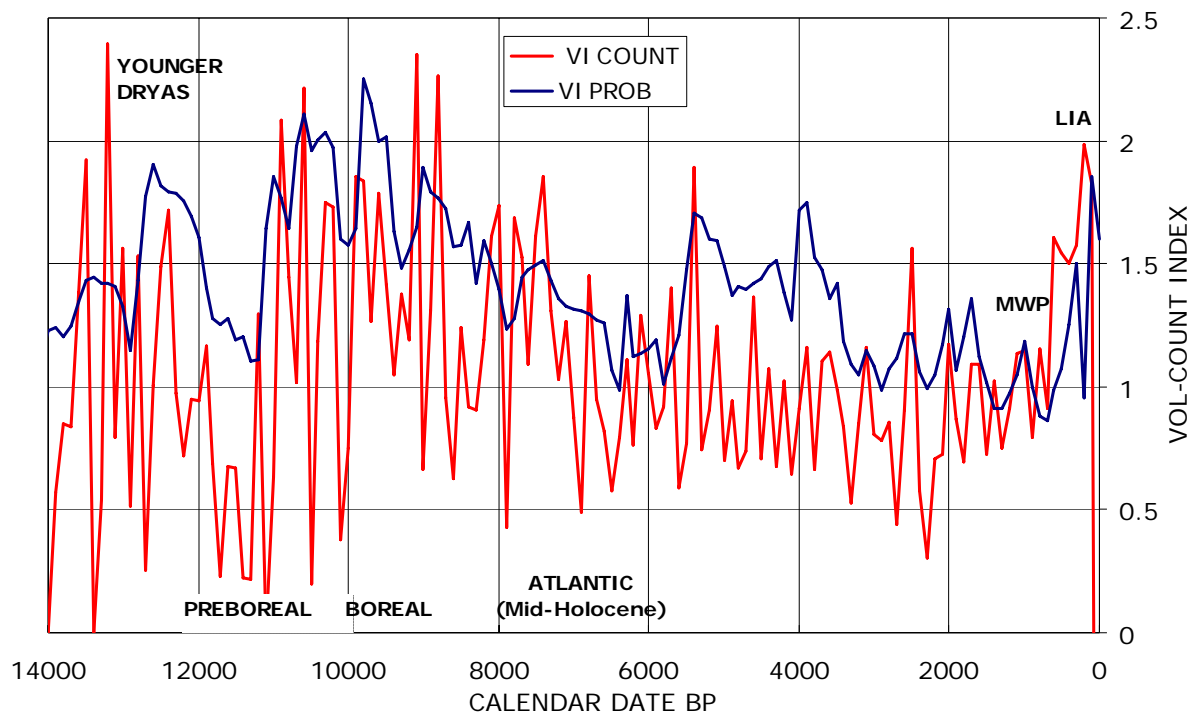

Fig. 2. Two detrended indices for late Quaternary volcanism from the database. The summed probability under the curve (VI PROB) is in blue, and a frequency distribution using century bins (VI COUNT) in red. Selected climatic periods and events including the Little Ice Age (LIA) and the Medieval Warm Period (MWP) are indicated.

\section{A cal 14-C late quaternary eruption database}

R. U. Bryson et al.

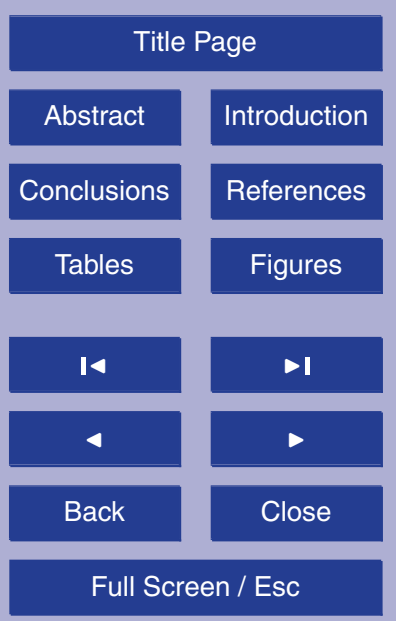

Printer-friendly Version

Interactive Discussion 